\title{
BEHAVIOUR OF RECTANGULAR RC COLUMNS RETROFITTED BY FIBRE REINFORCED POLYMERS UNDER AXIAL AND CYCLIC LOADING
}

\author{
H Shaheen \\ T Elrakib \\ Housing and Building Research Centre \\ I Shaaban \\ A Abdelrahman \\ Zagazig University \\ Ain Shams University
}

Egypt

\begin{abstract}
Retrofitting of reinforced concrete elements with fibre reinforced polymers, (FRP), wraps is one of the repair techniques used successfully for the last few years. Previous investigations have been concerned with the behaviour of rectangular $\mathrm{RC}$ columns strengthened by FRP wraps under axial loading. Consequently, a comprehensive study of the different parameters affecting the seismic behaviour of RC columns is important. The objectives of the research described in this paper are to carry out an experimental investigation to study the behaviour of rectangular RC columns wraped with FRP sheets under cyclic lateral and axial loading. The main parameters investigated in the research are: different anchorage systems, volumetric ratio of FRP and spacing between FRP layers. Five columns with dimensions $150 \times 450 \times 2300 \mathrm{~mm}$ were tested under both cyclic lateral and axial loading. Different recommendations are provided for the use of FRP in strengthening rectangular columns.
\end{abstract}

Keywords: CFRP, Columns, Cyclic loading, Seismic, Anchorage

H Shaheen is a Professor and Head of Department of RC, HBRC, Giza, Egypt. His research interests include the structural behavior of $\mathrm{RC}$, seismic analysis of such structures, advanced composite materials (ACM) and nonlinear static and dynamic analysis of RC structures.

I Shaaban is an Associate Professor for the analysis and design of RC structures in Civil Engineering Deptartment at Zagazig Univ.,Cairo,Egypt. He obtained his MSc from Ain Shams University, Cairo, Egypt, in 1988 and his PhD from University of Dundee, Scotland, in 1993. His research interests include the structural behavior of RC, seismic analysis of such structures and repair of RC structures.

A Abdelrahman is an Associate Professor for the analysis and design of RC structures in Civil Engineering Department at Ain Shams University, Cairo, Egypt. $\mathrm{He}$ is an associate member of ACI 440 code committee and his research interests include the structural behavior of $\mathrm{RC}$, retrofitting of RC structures and the use of ACM.

T Elrakib is an Assistant Researcher, Housing and Building Research Centre, Egypt. He obtained his MSc from Cairo University, in 1999. His research interests include the structural behavior of RC, retrofitting of RC structures with FRP . 


\section{INTRODUCTION}

Recently, attention has been focused on the use of fibre reinforced polymers FRP composite materials for structural rehabilitation. If correctly used, FRP composites can result in significant enhancement to both ductility and strength of RC members. Also, FRP can generally be applied while the structure is in use and with negligible changes in the member dimensions. Several studies on various aspects related to the subject have been published recently. The confinement of RC columns with FRP tubes, sheets and straps is among those research topics considered. Most of the previous work was undertaken on small columns, circular columns or columns subjected to axial loading only [1,2,5]. Rectangular columns, with aspect ratio 1 up to 5 , are commonly used for residential buildings. Consequently, a comprehensive study of the seismic behaviour of rectangular RC columns retrofitted by FRP is important.

This paper investigates the performance of rectangular RC columns wrapped by FRP sheets and subjected to a combined axial compression and cyclic flexural loading. Rectangular RC columns of aspect ratio 1 to 3 were tested under constant axial load and increasing cyclic lateral load up to failure. Carbon FRP, (CFRP) wraps were used with different volumetric ratio, spacing and with or without anchors. The displacement ductility, strength, stiffness and energy dissipation capacity were evaluated and compared for different techniques of retrofitting.

\section{TEST PROGRAM}

The test program includes five specimens with rectangular cross section designated as $\mathrm{C} 1$ to C5. The columns were tested horizontally under constant axial load combined with cyclic lateral load. The columns have a total height of $2300 \mathrm{~mm}$ and a cross section of $150 \times 450 \mathrm{~mm}$. It consisted of the right part of $1300 \mathrm{~mm}$ long and the left part with a length of $700 \mathrm{~mm}$ and a beam stub in the middle as shown in Fig.1. The right part of each specimen constituted the test portion. It represents a column extending from the beam-column connection to the point of infliction. The beam stub, which was heavily reinforced, provided a point of application for the lateral load.The dimensions of the beam stub were chosen so that the failure would occur in the column rather than at the joint. The left portion was also heavily reinforced and provided with two $6 \mathrm{~mm}$ thick steel plates, which were anchored to the specimen by steel bolts of $16 \mathrm{~mm}$ diameter, in order to force hinging into the right part and thereby reducing the amount of instrumentation needed. The longitudinal reinforcement ratio of the columns, in the right part, was $1 \%$ and the bars were uniformly distributed around the core perimeter. Stirrups in the same right part were $6 \mathrm{~mm}$ diameter bars every $150 \mathrm{~mm}$ with a volumetric ratio of $0.3 \%$. For the left part, stirrups were $8 \mathrm{~mm}$ diameter bars every $100 \mathrm{~mm}$. CFRP laminates were applied to strengthen the columns $\mathrm{C} 2$ through $\mathrm{C} 5$ with different schemes. The thickness of CFRP laminates was $0.11 \mathrm{~mm}$, while its tensile strength and modulus of elasticity were $2400 \mathrm{MPa}$ and $240 \mathrm{GPa}$, respectively. The characteristic compressive cube strength of the concrete after 28 days was $25 \mathrm{MPa}$ while the yield stress of the steel was $420 \mathrm{MPa}$ for the long reinforcement and $310 \mathrm{MPa}$ for stirrups.

\section{Test Specimens}

The overall test program consists of eleven specimens. This paper represents the results of only five columns, which were tested at the time of submission of the paper. The properties of the tested specimens are given in Figure 1 and Table 1 and summarized as follows: 
1. Specimen $\mathrm{Cl}$ is the reference specimen. A constant axial compression load of $0.15 f_{c u} A_{c}$ was applied on the specimen up to failure. This axial compression load was kept constant for all specimens.

2. Specimen C2 was wrapped in the transverse direction with two layers of lateral CFRP laminates of $100 \mathrm{~mm}$ width.The clear distance between laminates was $100 \mathrm{~mm}$ and the volumetric ratio of FRP was $0.2 \%$.

3. Specimen C3 was wrapped with one CFRP layer with a FRP volumetric ratio of $0.1 \%$.

4. Specimen $\mathrm{C} 4$ was wrapped with one layer of CFRP with no spacing between the layers. The volumetric ratio of FRP was $0.2 \%$.

5. Specimen C5 was wrapped with one layer of CFRP as for specimen C3. Steel plates of $50 \mathrm{~mm}$ width, $190 \mathrm{~mm}$ length, $12 \mathrm{~mm}$ thickness and $240 \mathrm{MPa}$ yield stress, were used to anchor the lateral laminates. The plates were discontinuous, this is to investigate the steel plates contribution to concrete confinement and increasing the ductility of columns, independently from their contribution to the flexural capacity of columns

Table 1 Details of the tested specimens

\begin{tabular}{|c|c|c|c|c|c|c|c|c|c|}
\hline No. & $\begin{array}{l}\text { COLUMN } \\
\text { DIMENSIONS } \\
(\mathrm{mm})\end{array}$ & NO. & $\begin{array}{l}\text { SPACING } \\
\quad(\mathrm{mm})\end{array}$ & $\begin{array}{l}\text { WIDTH } \\
(\mathrm{mm})\end{array}$ & $\begin{array}{c}\text { ANCHORAGE } \\
\text { SYSTEM }\end{array}$ & TYPE & $\begin{array}{c}\text { AXIAL } \\
\text { COMPRESSION }\end{array}$ & $\begin{array}{c}\text { RATIO } \\
\text { OF CFRP } \\
\rho(\%)\end{array}$ & $\begin{array}{c}\mathrm{As} / \mathrm{Ac} \\
\%\end{array}$ \\
\hline $\mathrm{C} 1$ & $150 \times 450$ & - & $\cdots$ & --- & --- & $-\cdots$ & $0.15 \mathrm{f}_{\mathrm{cu}}$ & 0 & 1.0 \\
\hline $\mathrm{C} 2$ & $150 \times 450$ & 2 & 100 & 100 & --- & CFRP & $0.15 f_{c u}$ & 0.2 & 1.0 \\
\hline $\mathrm{C} 3$ & $150 \times 450$ & 1 & 100 & 100 & -...- & CFRP & $0.15 f_{c u}$ & 0.1 & 1.0 \\
\hline C4 & $150 \times 450$ & 1 & 0 & 100 & -...- & CFRP & $0.15 \mathrm{f}_{\mathrm{cu}}$ & 0.2 & 1.0 \\
\hline C5 & $150 \times 450$ & 1 & 100 & 100 & 2 steel plates & CFRP & $0.15 f_{c u}$ & 0.1 & 1.0 \\
\hline
\end{tabular}

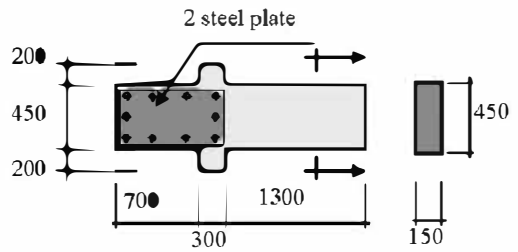

Specimen C1

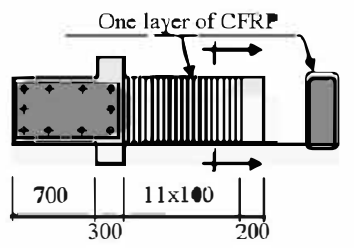

Specimen C4

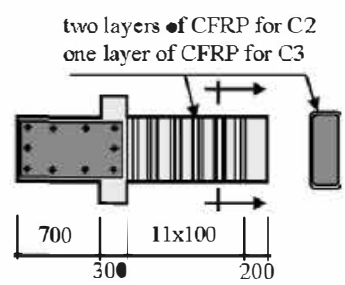

Specimen C2\&C3

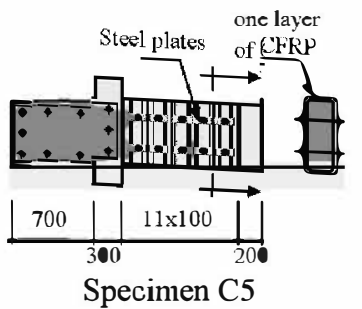

Figure 1 Details of CFRP wrapping for tested columns 
CFRP sheets were wrapped after the concrete reached an age of 28 days. The wrapping procedure included surface preparation of the columns by removing a layer of concrete of thickness 10 to $15 \mathrm{~mm}$ around the specimen at the predetermined locations using a manual hammer followed by a blower to remove the loose particles. Then, a suitable grout was used in leveling the sides of the roughened locations and in rounding their sharp corners. The epoxy adhesive resin (S\&P Resin 55) was mechanically-mixed and applied evenly on the surface using a roller. Then, the CFRP sheets were smoothly hand-laid to achieve a wrinklefree surface and provide a complete wrapping of the columns.

\section{Instrumentation}

Two linear variable differential transducers (LVDTs) with stroke $+/-200 \mathrm{~mm}$ and sensitivity $0.1 \mathrm{~mm}$ were mounted at the top and bottom sides of the critical section of each column adjacent to the stub. The LVDTs were used to measure the concrete strain and the average section curvature over $200 \mathrm{~mm}$ length in the plastic hinge region. The lateral displacement control sensor used in testing is a long LVDT $+/-100 \mathrm{~mm}$ stroke with $0.1 \mathrm{~mm}$ sensitivity. The sensor was mounted on a handling unit, which was located on the ground under the lateral load head. All the LVDTs were attached to the specimen using $6 \mathrm{~mm}$ bolts. Four electrical strain gages were glued on the longitudinal and transverse reinforcement of each specimen. In addition, six electrical strain gages were glued on the CFRP sheets after cleaning and smoothing the surface.

\section{Test Setup and Procedure}

Two independent reaction frames were used in the testing setup, as shown in Figure 2 . The first frame was a $2000 \mathrm{kN}$, large-scale testing double portal, open reaction frame, while the second frame was a $3000 \mathrm{kN}$, closed, horizontal, reaction frame.

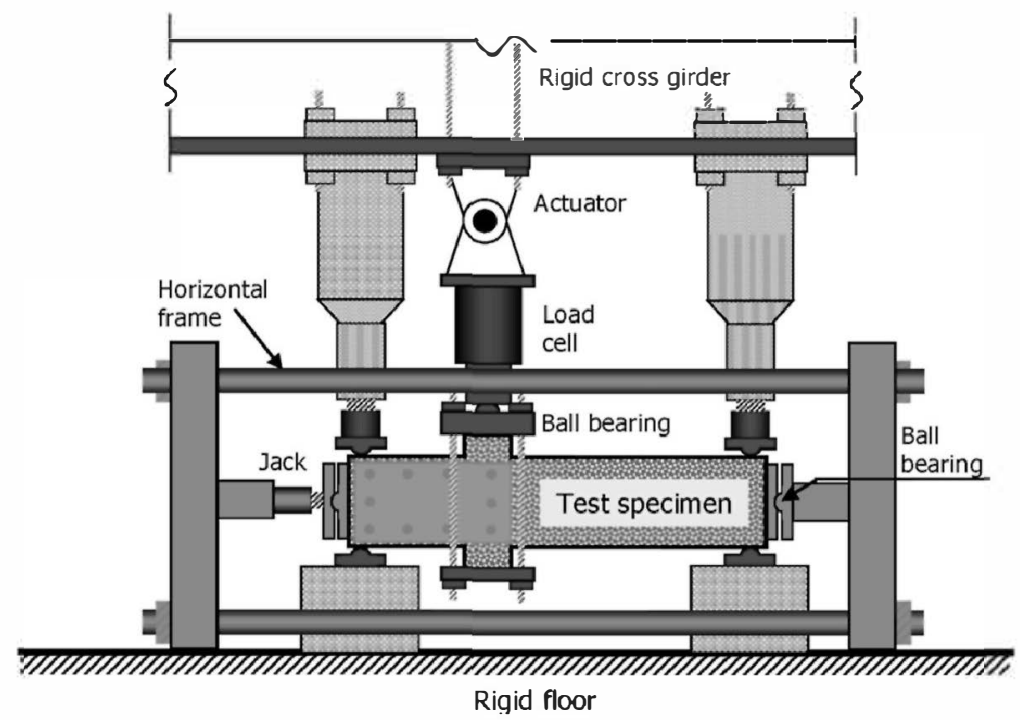

Figure 2 Schematic of test setup 
The lateral reversed cyclic displacement was applied at the stub of the beam-column joint using a double acting hydraulic cylinder of $600 \mathrm{kN}$ compression capacity and tension capacity of $400 \mathrm{kN}$. The hydraulic cylinder was attached to the cross girder of the double portal frame. The cylinder was equipped with a tension/compression load cell of $+/-680 \mathrm{kN}$ capacity to measure lateral load. The compression and tension lateral loads were transmitted to the specimen by two rigid plates located at the top and bottom of the stub and tied together with four threaded bars around the stub. The axial compression load was applied by a manual hydraulic cylinder of $900 \mathrm{kN}$ capacity. At the beginning of each test, the required axial load was applied at the target value and kept constant throughout the test. The reversible hydraulic jack was used to apply an increasing cyclic lateral load in displacement increments according to the history shown in Figure 3.

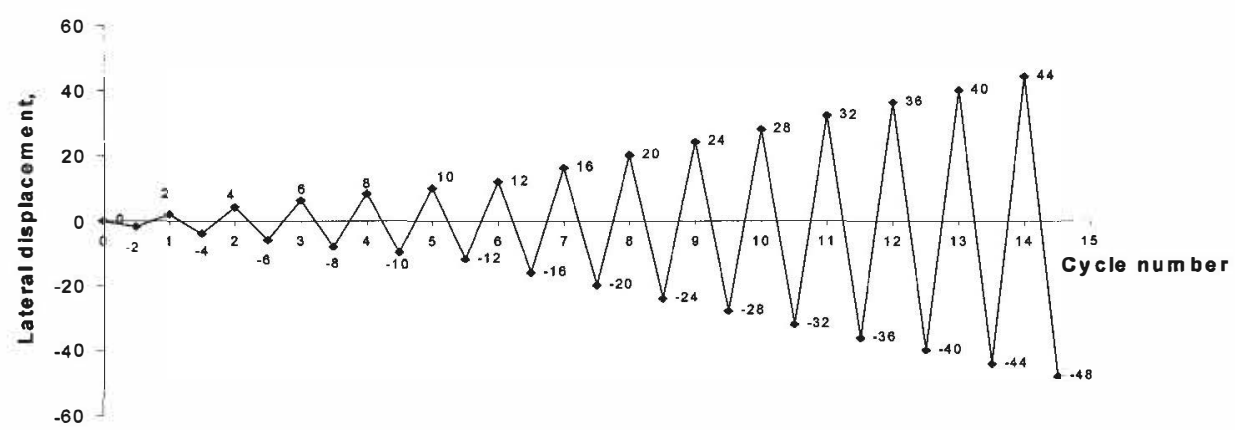

Figure 3 Nominal lateral loading history

\section{OBSERVED BEHAVIOUR}

The lateral load-displacement hysteresis loops of the control specimen are shown in Figure 4. The ultimate lateral load was $237.1 \mathrm{kN}$. The load-displacement relationship was linear until the ultimate load was achieved. Progressive drop in the strength occurred at a lateral displacement of $4 \mathrm{~mm}$. Failure load was reached at a lateral displacement of $6.75 \mathrm{~mm}$. The specimen failed in a brittle shear failure mode. A major diagonal tension crack appeared at a lateral load of $114.0 \mathrm{kN}$ and extended up to failure as shown in Figure 5.

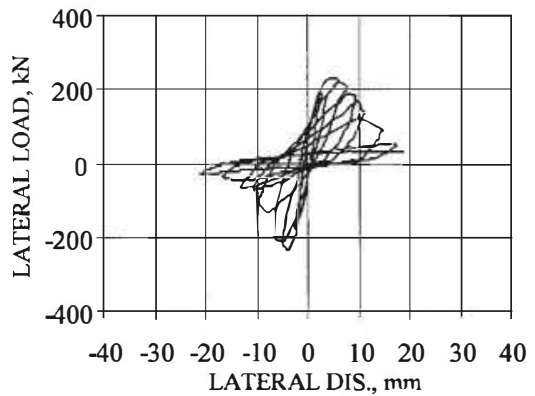

Figure 4 Lateral load displacement of $\mathrm{Cl}$

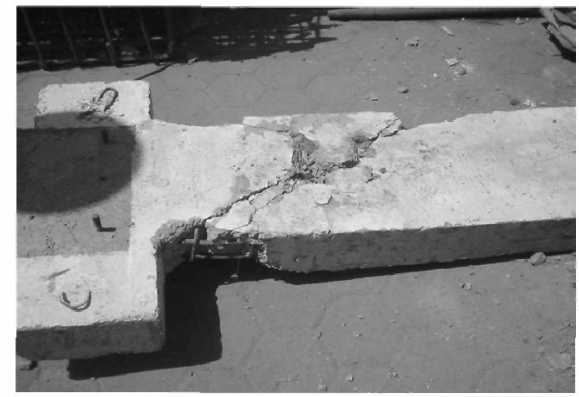

Figure 5 Failure of Specimen C1 



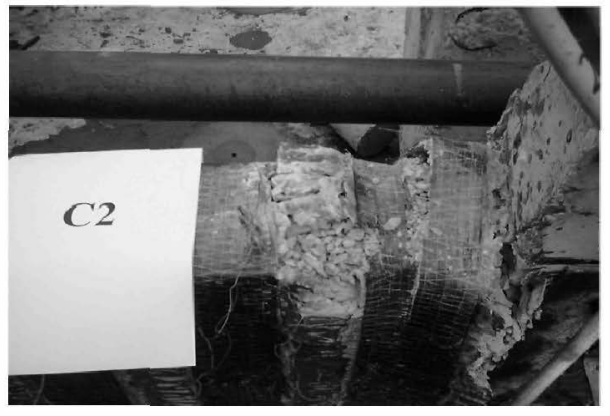

Figure 10 Failure of Specimen C2

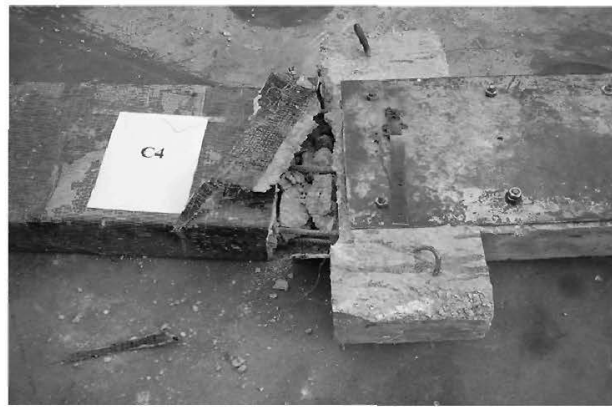

Figure 11 Failure of Specimen C4

Table 2 Lateral load-displacement test results

\begin{tabular}{ccccccc}
\hline \multirow{2}{*}{ SPECIMEN } & \multicolumn{2}{c}{$\begin{array}{c}\text { VISIBLE CRACKING } \\
\text { LEVEL }\end{array}$} & \multicolumn{2}{c}{$\begin{array}{c}\text { ULTIMATE LOAD } \\
\text { LEVEL }\end{array}$} & \multirow{2}{*}{$\mathrm{P}_{\mathrm{u}} /\left(\mathrm{P}_{\mathrm{u}}\right.$ of C1) } & $\begin{array}{c}\text { FAILURE } \\
\text { CYCLE }\end{array}$ \\
\cline { 2 - 5 } & $\mathrm{P}_{\mathrm{cr}} \mathrm{kN}$ & $\Delta_{\mathrm{cr}} \mathrm{mm}$ & $\mathrm{P}_{\mathrm{u}} \mathrm{kN}$ & $\Delta_{\mathrm{u}} \mathrm{mm}$ & & \\
\hline $\mathrm{C} 1$ & 114.0 & 3.5 & 237.1 & 4.04 & 1 & 4 \\
$\mathrm{C} 2$ & 275.0 & 8.5 & 348.5 & 27.80 & 1.46 & 11 \\
$\mathrm{C} 3$ & 200 & 4.8 & 284.8 & 16.09 & 1.20 & 8 \\
$\mathrm{C} 4$ & 230 & 6.4 & 329.8 & 12.10 & 1.39 & 9 \\
$\mathrm{C} 5$ & 215 & 5.5 & 319.1 & 11.85 & 1.34 & 9 \\
\hline
\end{tabular}

\section{ANALYSIS OF TEST RESULTS}

The strength envelope, which is the relationship between the peak load at each cycle and the corresponding displacement, is presented for the tested columns in Figure 12. The lateral strength increases considerably for all the wrapped specimens.

The highest strength was that of specimen C2 with two CFRP wraps, $46 \%$ higher than the control column. Specimen C3, with one layer of CFRP, produced the lowest increase which was $20 \%$ higher than the control column. This increase in the flexural strength is atributed to the confinement provided by CFRP which resulted in an increase in the concrete strength and strain. It should also be noted that the longitudinal reinforcement bars reached the strain hardening, consequently the stress in the steel bars exceeded the yield stress leading to an increase in the overall strength of the retrofitted columns.

Specimen C2 also survived more cycles than all the other specimens as shown in Table 2. The column C5 with anchored CFRP wraps had ultimate load close to C4 with zero spacing between wraps, (34\% and $39 \%$ higher than the control specimen $\mathrm{Cl}$ ), despite that the CFRP ratio was $50 \%$ less for the anchored column. The column C3 with one CFRP wrap and no anchors, had $20 \%$ higher strength than the control specimen. 


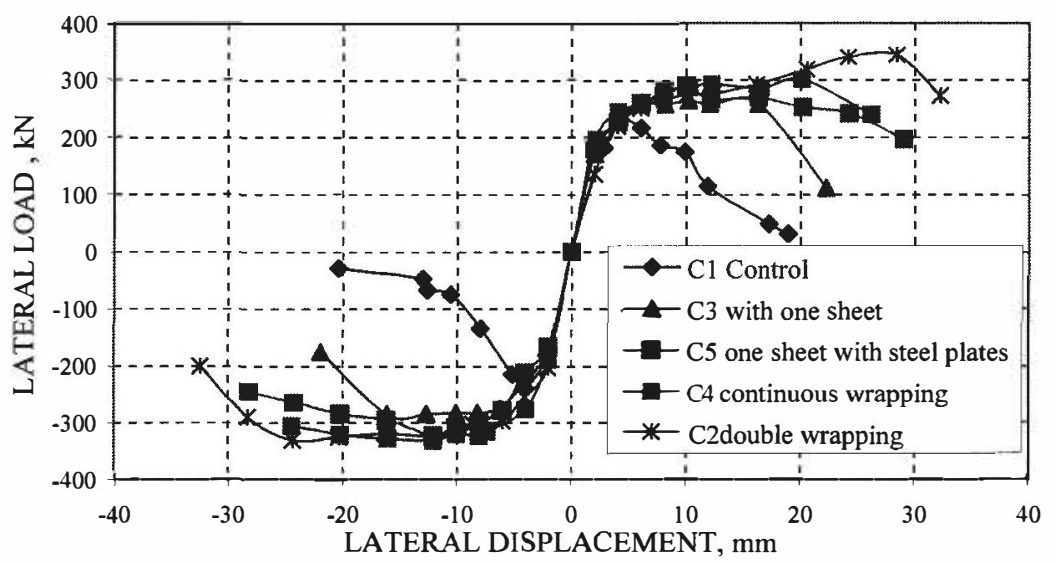

Figure 12 Hysteresis loops envelope of lateral load against displacement

\section{Yield Displacement}

The yield displacement $\Delta_{y}$ of an equivalent elasto-plastic system with reduced cracked stiffness was calculated from the lateral load-displacement curve as the corresponding displacement at the intersection of the secant stiffness at a load level of $75 \%$ of the ultimate lateral load and the tangent at the ultimate load. The strength envelope is used to determine the yield displacement [3].

\section{Displacement Ductility Factor}

The failure load was taken equal to $75 \%$ of the ultimate load on the descending branch on the strength envelope and the corresponding displacement $\Delta_{\mathrm{f}}$ was computed. The displacement ductility factor is defined as the ratio between the displacement at failure load, $\Delta_{\mathrm{f}}$, and the yield displacement, $\Delta_{\mathrm{y}}$ as given by Equation (1).

$$
\text { Displacement Ductility factor }=\Delta_{\mathrm{f}} / \Delta_{\mathrm{y}}
$$

The control column failed in a brittle shear mode at a low ductility factor of 2.3 as shown in Table 3. All the strengthed columns failed in a ductile mode with ductility factors more than 4.5. It should be noted that the satisfactory level of ductility is achieved by a minimum of ductility factor of 3 [4]. Specimen C2 with double layer produced the highest value of ductility factor (3 times that of $\mathrm{C} 1$ ).

This result highlights the role of increasing the volumetric ratio of CFRP in enhancing both the ductility and lateral strength of the columns. It was observed that the ductility of columns $\mathrm{C} 4$ and $\mathrm{C} 5$ were similar despite that the latter has 50\% less in the CFRP wraps. The ductility factors of C4 and C5 were 2.72 and 2.25 times that of the control column, respectively. In addition, the accumulated ductility factors of the two columns were 4.39 and 4.72 times that of the control column. This is due to the anchorage system used for column C5. 
Table 3 Ductility analysis and energy index

\begin{tabular}{ccccc}
\hline SPECIMEN & $\begin{array}{c}\text { YIELD } \\
\text { DISPLACEMENT, } \\
\Delta_{\mathrm{y}} \mathrm{mm}\end{array}$ & $\begin{array}{c}\text { FAILURE } \\
\text { DISPLACEMENT } \Delta_{\mathrm{f}} \\
\mathrm{mm}\end{array}$ & $\begin{array}{c}\text { DUCTILITY FACTOR ENERGY } \\
\Delta_{\mathrm{f}} / \Delta_{\mathrm{y}}\end{array}$ & $\begin{array}{c}\text { INDEX } \\
\text { C1 }\end{array}$ \\
\hline C2 & 2.85 & 6.75 & 2.36 & 8.9 \\
$\mathrm{C} 3$ & 4.40 & 31.91 & 7.25 & 204.3 \\
$\mathrm{C} 4$ & 3.94 & 18.91 & 4.78 & 66.3 \\
$\mathrm{C} 5$ & 4.10 & 26.42 & 6.44 & 122.9 \\
\hline
\end{tabular}

\section{Energy Dissipation}

The dissipated energy was computed for each cycle as the area enclosed by the lateral loaddisplacement hysteresis loop for the given cycle. The accumulated dissipated energy is plotted versus the lateral displacement for the tested specimens in Figure 13.

A non-dimensional energy index based on Ehsani [5] was also used to evaluate the energy dissipated for the tested specimens. The index appears to be a reliable indicator of the performance of columns. This is due to the fact that it accounts for the cracked stiffness, yield load and displacement, as well as the dissipated energy of each cycle. The non-dimensional form of the index facilitates the comparison of specimens of different sizes and scales. Formulation to evalute such index is explained in [5].Compared with the retrofitted columns, specimen $\mathrm{C} 2$ possessed significantly larger energy dissipation than the other columns as it achieved the largest index of 204. Column C3 had the lowest index of 66.

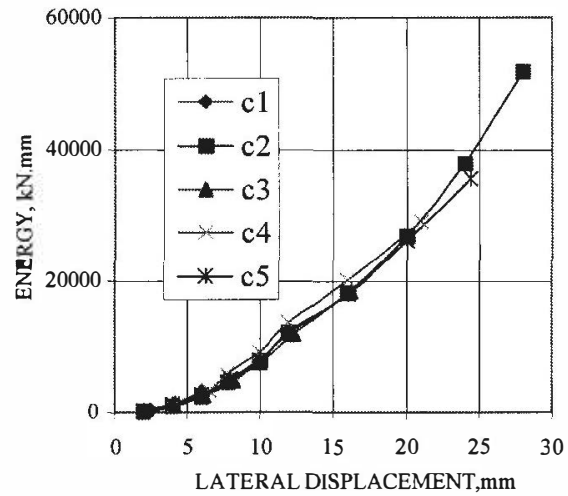

Figure 13 Accumulated energy For columns up to failure load

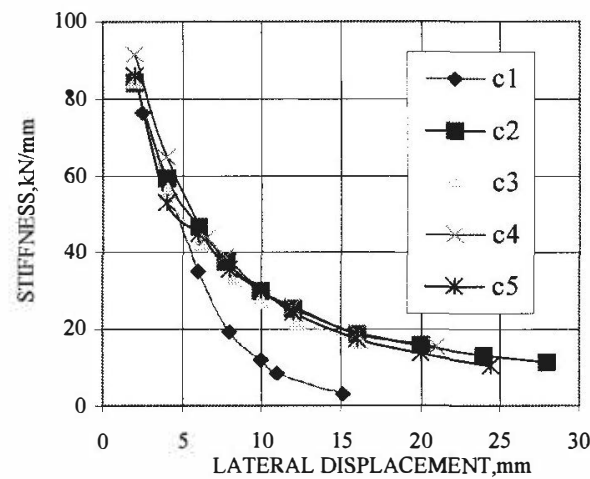

Figure 14 Stiffness degredation curves 


\section{Stiffness Analysis}

The cracked stiffness of each tested specimen, $\mathrm{Ki}$, is calculated for every loading cycle. The cracked cycle stiffness is computed as the ratio of the sum of the peak tension and compression loads to the sum of the corresponding tension and compression displacements as illustrated in [1]. It can be seen from Figure 14 that the initial stiffness of all columns including the control one was approximately the same. At high load levels, the retrofitted columns showed higher stiffness than that of the control column. This presents a good advantage of the CFRP wrapping technique, as the strengthed columns will not attract more horizontal force at low load levels during any seismic loading. Also, a close examination of these plots indicates that the rate of stiffness deterioration of the retrofitted columns under large reversed cyclic oading was lower than that of the control column.

\section{CONCLUSIONS}

CFRP wraps showed an excellent enhancement to the overall behavior of the columns and the following conclusions can be summarized for the studied cases:

1. All the wrapped specimens failed in a ductile flexural mode, instead of the brittle shear mode of the original column.

2. Increasing the CFRP volumetric ratio improved the overall behaviour of the column and increased the lateral strength. However, it is recommended that the number of layers be increased instead of reducing the spacing between the layers.

3. It was observed that the behaviour of columns $\mathrm{C} 4$ and $\mathrm{C} 5$ was similar although the CFRP ratio was $50 \%$ less for column $\mathrm{C} 5$. This suggests that a proper choice of the anchorage system may be more feasible than reducing the spacing between sheets.

4. Unlike the conventional techniques for column strengthening, the initial stiffness of the retrofitted columns was similar to that of the original one.

\section{REFERENCES}

1. SAADATMANESH, H., EHSANI, M., AND JIN, L. (1997) “ Repair of EarthquakeDamaged RC Columns with FRP wraps ”, ACI structural Journal, V. 94, No. 2.

2. HOSNY, A., SHAHEEN, H., ABDELRAHMAN, A., AND EL-AFANDY, T. (2002) “ Strengthening of Rectangular RC Columns Using CFRP”, M.Sc.Thesis, Faculty of Eng. Ain Shams Univ.

3. PARK, R., AND PAULAY, T. (1975) “ Reinforced Concrete Strucrutes”, John Wiely and Sons, New York, N.Y.

4. PRIESTLY, M., AND PARK, R. (1986) "Strength and Ductility of Concrete Bridge Columns under Seismic Loading", ACI Structural Journal, V. 84, No. 1.

5. EHSANI, M., AND WIEGHT, J. (1990) "Confinement Steel Requirements for Connections in Ductile Frames", ASCE Structural Journal, V. 116, No. 3. 